\title{
A Way Forward To Promote The Farming Contracts Between Firms And Farmers In Cultivation Productions: A CASE STUDY Of VIETNAM
}

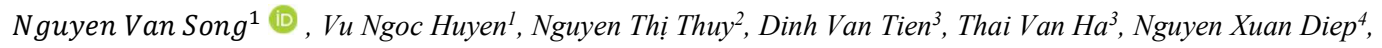 \\ ${ }^{1}$ Vietnam National University of Agriculture (VNUA), Trau Quy, Gia Lam, Hanoi, Vietnam \\ ${ }^{2}$ Hanoi University of Industry (HAUI), Minh Khai, Bac Tu Liem, Hanoi, Vietnam \\ ${ }^{3} \mathrm{Ha}$ Noi University of Business and Technology (HUBT), Vinh Tuy, Hai Ba Trung, Ha Noi, Vietnam. \\ ${ }^{4}$ Thai Nguyen University of Economics \& Business Administration (TUEBA), Thai Nguyen, Vietnam.
}

Emails: nguyensonghua@gmail.com, vungochuyen.vnua@gmail.com, thuynguyen17072007@gmail.com, dvtien.napa@yahoo.com, vanha280182@gmail.com,nguyenxuandiep@gmail.com.

Corresponding author is Dr. Vu Ngoc Huyen,

Email of Corresponding author: vungochuyen.vnua@gmail.com

\begin{abstract}
In an age of market liberalization, globalization, and expanding agribusiness, there is a danger that small-scale farmers will find difficulty in fully participating in the market economy. One of the solutions to solve the above situation is to strengthen linkages between farmers and firms through contract farming. The purpose of this study is to assess the factors affecting the level of linkages between businesses and farmers in crop development in Thai Binh province, Vietnam. The two main research methods used were exploratory factor analysis (EFA) and regression analysis with survey data which was conducted from 300 farmers, 10 firms, and 15 factors related to contract-farming. The results indicated that there are 5 factors that significantly affect the level of participation of farmers in the linking process, the order of impacts from strong to weak is as follows: (1) Commitment and sharing of benefits and risks between farmers and firms in the linking process, (2) Issues related to management skills and enterprises capacity of link firms, (3) Price issues that farmers are interested in in the process of implementing links with firms, (4) Policy environment - Institutions related to farmer contracts between firms and farmers, (5) Household awareness about the benefits brought about by farmer contracts with firms. Based on results, a number of specific solutions have been proposed to enhance the efficiency of farming contracts between firms and farmers in cultivation production.
\end{abstract}

Keywords: farm contracts, firms, farmers, cultivation production, Thai Binh.

\section{Introduction}

Linking in production and business is always the direction to encourage the development of many economies in the world. Vietnam's agricultural sector is still small, fragmented and traditional agriculture. Therefore, cooperation and alignment in the industry are more necessary than ever (Tran Quoc Nhan, 2012). However, the results of implementing this linkage in Vietnam were not as expected. Farmers have remained on the sidelines of the growth; they are not keen on joining the agricultural association and accepted to keep the traditional farming practices with many risks (Quang Sang, 2019). In the total 50,000 firms involved in the agricultural sector, only about 1,000 are directly linked to farmers (Bao Loan \& Duong Thanh, 2019). Investment in agricultural production is not effective, high risks; besides the support 
policy for firms to invest in agricultural production is not specific, so the largest enterprises are not interested to invest in agriculture. The farmer contract between firms and farmers was not strong and sustainable because there was no mechanism for sharing profits and risks, mainly still in the form of negotiation for buying and selling (Nguyen Van Chi, 2020). The proportion of commodity agricultural products that are consumed through contracts between farmers and firms are still low. The form of contract for consuming agricultural products is only done mainly in the relatively large-scale production sectors such as rice and phantasies, but especially for the vegetable and fruit industry, it is still through merchant (Quynh Anh, 2020).

Thai Binh is a Vietnamese administrative unit and a coastal province in the Red River Delta. By the end of 2018, Thai Binh ranked 13/63 provinces and cities in terms of population, ranked 29th in Gross Regional Domestic Product (GRDP) and ranked 8th in speed GRDP growth (Thai Binh Statistical Office, 2018). Thai Binh is the only plain province without hills and mountains, suitable for agricultural production. Agriculture is the main industry, accounting for a large proportion in the value of agricultural products of the province (over 50\%), the area of food crops in 2017 was about 171,9 thousand hectares, of which the rice area was 158,7 thousand ha (General Statistics Office, 2017). However, the current implementation of farming contracts between firms and farmers in Thai Binh province has been still very limited.

In order to improve the effectiveness of production linkages, the Government of Vietnam has issued many different policies. The government perceives contract farming as an excellent opportunity to boost rural economic development; it reveals its strong interest in contract farming through the issuance of a legal framework for its implementation (Hélène et al., 2019). Decision No. 80/2002/QD-TTg of June 24, 2002 of the Prime Minister (the policy of linking 4 houses) and the Directive No. 25/2008/CT-TTg of October 10, 2008 of the Prime Minister The Government has strengthened the direction of consuming agricultural products through contracts. These policies have positively affected the formation of many raw material areas associated with processing and consumption, especially for sugarcane and tobacco production, milk, some vegetables. However, the promotion and implementation of large-scale contract farming require information on the determinants that affect farmers'participation, which is very important for key planners books to develop more appropriate programs. However, despite growing adoption rates, to the best of our knowledge no studies evaluating the inclusiveness of farming contracts and analyzing the factors that influence people's participation in farming contracts in Vietnam.

Several studies have attempted to assess the determinants of contract farming participation by farmers for specific crops and the actors in the linkage. The model of "linking four houses" has been researched, built, and applied in rural agriculture production practices in Tra Vinh province in the works of Vo Huu Phuoc (2010), and in the Red River Delta of Nguyen Tat Thang (2014), Enterprises and Farmers are the two main actors of linkages in agricultural production. In particular, Enterprises are the engine of the linkage and play an important role in linking the remaining "3 houses" to form production areas; supporting inputs and purchasing products for farmers; step by step towards branding of agricultural products. Le Thi Kim Oanh et al. (2016) focuses on analyzing the benefits of tea producers that sign contracts with companies in term of tea marketing channels in Phu Tho province, the study found that contract farmers received lower price than non-contract farmers did in exchange for higher stability of price and better market access. As a result, it is highly recommended that small tea farmers should participate in contract farming in Phu Tho Province, Vietnam. Nguyen Dinh Phuc et al. (2017) studied the annual sugarcane production activity in Gia Lai province, the study pointed out 4 factors that 
have a great influence on the ability of sugarcane farmers to participate in the associated model including the capital (95.38\%), agricultural extension (94.98\%), experience $(65.27 \%)$, and area $(61.09 \%)$.

The above studies analyzed different topics of linkage issues in Vietnam. However, there are many scientific gaps that can develop: The fact that the process of implementing business links and farmers in each locality is different. Lessons learned from localities are only for reference to the process of implementing links in Thai Binh. On the other hand, to our understanding, there has not been any scientific and comprehensive and systematic research on how to link businesses and farmers in the development of crop production in Thai Binh province.

Against this background, this study contributes to the literature in three ways. First, we generalized the situation of agricultural production linkages between farmer households and businesses in Thai Binh province. Secondly, we modeled the factors that influence people's participation and analyzed the impact of each of them.Thirdly, we formulate policy recommendations to improve linkage efficiency in production in Thai Binh and can be applied to other localities.

\section{Literature reviews}

Hirschman (1958) divided the concept of farmer contracts based on industry and interdisciplinary relationships: Links include backward linkages and forward linkages. The backward linkages arise from the demand for input supply of a newly established industry, while forward linkages arise from using that sector's output as the input of the pull-along activities.

Contract farming, as an institution in agriculture, has a long history. Various forms of this institutional arrangement were employed by United States multinationals in Central America at the beginning of the 20th century, and by the Japanese to secure sugar production in Taiwan from 1885 (Runsten \& Key, 1996).

During the period 1930-1950, contracting was used increasingly in many food and fibre sectors. The fruit and vegetable canning sectors expanded in the United States and Europe (Little \& Watts, 1994; Clapp, 1994). From the late 1950s, Mexican growers increasingly supplied the American markets with fruit and vegetables under contract (Watts, 1994), and in the period 1960-80 there was a significant increase in contracting for vegetables, fruit, nuts and seed crops (Kilmer, 1986). Contract farming has also spread rapidly in Asia, Latin America and Africa owing to the higher returns earned by high-value export crops and the impact of new technologies (Clapp, 1994; Staatz $\&$ Eicher, 1998). Some places, forms of contracting are dependent on specific institutions such as marketing orders and bargaining cooperatives (Sporleder, 1992). The contract could specify the price, quantity, quality, the provision of agribusiness inputs (Sporleder, 1992; Runsten \& Key, 1996). Reardon and Barrett (2000) have observed that the agricultural industrialization process in many developed countries has brought a number of effects in regulating the supply chains that make them more closely connected.

Boehlje (2000) argues that in many developed countries, agricultural production is changing from an industry dominated by family-based, small-scale farms or firms to one of larger firms that are more tightly aligned across the production and distribution value chain. This implies that changes in agricultural industrialization are needed. This has led to the introduction of various forms such as vertical links and alliances, which become an outstanding feature of the agricultural supply chain. From the above points of view, the signing of contracts allows farmers to overcome barriers to integration into the world economy (Carney, 1988; Clapp, 1994; Jackson 
\& Cheacher, 1994; Little \& Watts, 1994; Royer, 1995; Pasour, 1998; Delgado, 1999; Vellema, 2000). Contracting could also improve access to capital and credit (Hudson, 2000).

Contracting farmers can reduce production costs and increase production and income as a result of their use of new technology and their access to company inputs (Watts, 1994; Clapp, 1994). Contracting farmers can stabilise output of the product and stabilise income. At the same time, contracts may simplify production and marketing decisions, thus improving the farmer's effectiveness (Hudson, 2000). Contracting farmers can increase profit opportunities through a greater product range and differentiated products (Pasour, 1998), or by diversifying out of traditional crops in developing countries in order to grow high-value crops and thereby increase their income (Williams, 1985; Levin, 1988; Delgado, 1999).

Saggi (2002), Giroud \& Scott-Kennel (2006), Unctad (2001) have concluded that horizontal linkages shows the interaction between foreign and local enterprises in the production of goods and services in the same production phase. The most important effect is called the spillover effect, which arises as a side effect of the activities of foreign companies in the economy (Coe \& Helpman, 1995; Coe et al., 1997; Giroud \& Scott-Kennel, 2006; Dieppe \& Mutl, 2013). Fujita \& Mori (2005), Hussain \& Planning (2000) have concluded that there are two main types of linkages, creating a driving force in cross-industry interactions. The first type is called economic link (E-farm contracts), including activities related to the production and trading of goods and services. The second type is called knowledge link (K-farm contracts), including human activities in creation and transfer of knowledge, thus creating the knowledge spreading effect.

Mesquita \& Lazzarini (2008) concluded that linkages have a combination of vertical and horizontal links, which appear in the development and integration process when the relationship between households, facilities and enterprise is a combination of cooperation and competition. These units, on the one hand, link together horizontally to form groups or cooperatives in order to improve the competitiveness of each member, limiting the situation of level price squeezing; On the other hand, groups or cooperatives that are formed in close linkage with processing enterprises or groups of households and cooperatives are also the suppliers of products to the next actor of the process of production and business.

Otsuka et al. (2016) review focuses on literature in developing countries; they find that although contract farming contributes to the improvement of farmers' income by introducing new crops and production methods, there is room for strengthening its effects on poverty reduction through policy. Olounlade et al. (2020) found evidence of significant negative effects on rice production income at a $1 \%$ level. The more the rice farmers join in contract farming, the lower the farm income became. Hung Anh \& Bokelmann (2019), analyze the market preference of coffee farmers in Vietnam, found out formal institution brings better market access for coffee farmers, but main issues are regarding opportunistic behavior, imperfect market knowledge, traditional farming habits, and contract noncompliance, which have resulted in a lower preference for the market of processors/exporters.

Through the theory of contract farming, it can be seen that contract farming gives contract farmers many benefits such as easy market access and more stable market, the contract could specify the price, quantity, quality, the provision of agribusiness inputs. The form of contractual cooperation helps businesses and farmers have certain "constraints". Through an economic contract, the parties must be responsible and obliged to implement the terms of the contract. These are also the scientific bases for us to build a hypothetical research model for this research. 


\section{Research methodology}

\subsection{Conceptual Research Framework}

This study aims to explore the factors related to the level of participation of farmers in linkage with firms in Thai Binh province. There were six factors that were expected to affect the level of participation of farmers as follows: (1) Awareness of farmers about benefits of farmer contract with firms; (2) Commitments in the process of linking with firms; (3) Sharing benefits and risks between farmers and linked firms; (4) Management skills and business competence of linked firms; (5) Policy environment - Institutions related to the farmer contract between firms and farmers; (6) Price issues that farmers are interested in in the process of implementing farmer contracts with firms.

The process of developing the survey table and conducting data collection survey has been carried out in the following main stages.

Fig. 1 Model of building survey table and conducting data collection survey

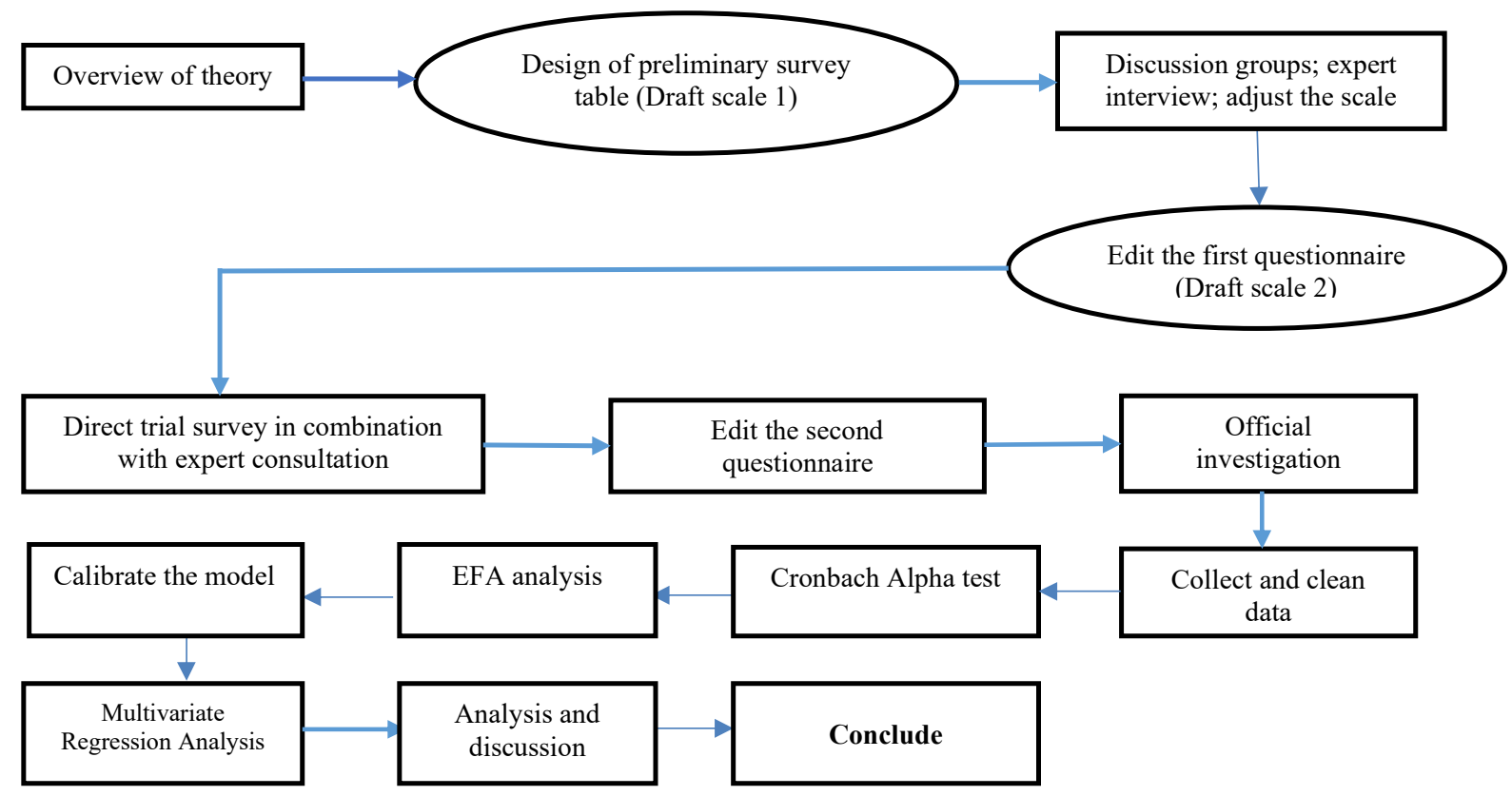

Source: Summary of the author (2019)

\subsection{Data Collections}

\subsubsection{Secondary data}

Secondary data used in the study include: data on land, population and labor of Thai Binh province and data on the situation of business-farmer farmer contracts in crop production. These secondary data were collected from the available public sources: General Statistics Office, Statistical Office of Thai Binh Province, Department of Agriculture and Rural Development of Thai Binh Province, enterprises participating in the association in the province, Research related to links in Thai Binh province.

\subsubsection{Primary data}

Primary data was collected through survey methods, direct interviews with enterprises and farms. Primary data was collected through two main methods: Survey method, direct interview with enterprises, farmers, farms and Expert method including business leaders, the professional officials in the localities. 
The author has surveyed and collected 300 questionnaire surveys of farm households who have participated, are participating and have not joined the link. The author also conducted indepth interviews with provincial, district and cooperative managers, investigating enterprises involved in agricultural production in Thai Binh province.

The author has selected 3 districts to represent for the survey: Dong Hung district, $\mathrm{Vu}$ Thu district and Kien Xuong district. These have been the three typical districts for linking firms and farmers in crop development in Thai Binh province and they have achieved certain results in implementing the farmer contract. The survey sample selection of the author is large enough to be representative to carry out the study.

The set of questionnaires was distributed to 300 people from farmers who have participated, are participating and have not joined the link, 10 firms and 15 professional officials in the localities (Table 1). The set of questionnaires was divided into 2 parts, the first part involved the respondent background, while the second part included 5 Likert scale ranging from strongly disagree (1) to strongly agree (5) direct questionnaire about the level of participation of farmers.

Table 1. Summary of survey samples on farmer contracts between firms and farmers

\begin{tabular}{|c|c|c|}
\hline $\begin{array}{c}\text { Number of } \\
\text { sample survey }\end{array}$ & $\begin{array}{c}\text { Subject matter } \\
\text { investigated }\end{array}$ & Location of investigation \\
\hline 125 & Farmer & Dong Hung district \\
\hline 82 & Farmer & Vu Thu district \\
\hline 93 & Farmer & Kien Xuong district \\
\hline 10 & Enterprise & Thai Binh province \\
\hline 15 & Managers & $\begin{array}{l}\text { Managers of provinces, districts and } \\
\text { cooperatives }\end{array}$ \\
\hline
\end{tabular}

Source: Summary of the author (2019)

\subsection{Data analysis}

This study performed two main analyses that are Exploratory Factor Analysis (EFA) and Multivariate Regression Analysis using IBM SPSS Statistics 22 package.

Exploratory factor analysis is used for reducing the number of variables to a smaller set of underlying summary variable or component. This method is one of a statistical method to uncover the underlying structure of a relatively large set of variables (Norris \& Lecavalier, 2010). In Exploratory Factor Analysis (EFA), firstly it is looking at the Kaiser-Meyer-Oikin (KMO) value that measure of sampling adequacy for the variables is close to 1.0 (Latif et al., 2012; Latif et al., 2018; Kaiser, 1974). The values more than 0.6 consider reliable as recommended by Nunnally (1978). According to Cristobal et al. (2007), the item with corrected item - total correlation lower than 0.30 are not acceptable. Similarly, the Bartlett's Test of Sphericity to see the sufficiency correlation items to proceed in the analysis when it is significant at $p<0.001$, which means that there are some relationships between the items. Since both of the tests were significance, it is suggesting that the data is appropriate to proceed with data reduction procedure to group the items into acceptable components (Habidin, 2013). The number of factors is determined based on the Eigenvalue index (The value of the variance divided by each factor) representing the variance explained by each factor. According to Cerny \& Kaiser (1977) factors with Eigenvalue less than 1 will be excluded from the model. Variance explained criteria: the total variance explained must be greater than 50\%. Using Principal components extraction method with varimax rotation and stopping points when extracting elements with Eigenvalues greater than 1 with observed variables. Then, all 32 items are loaded into respective factor with a 
minimum factor loading of 0.4 (Habidin, 2013; Hatcher, 1994). A reliability test is conducted to ensure all factors are accepted as being reliable for the research in order to enhance the accuracy of the assessment and evaluations (Habidin, 2013).

After completing the Exploratory Factor Analysis, the variables do not guarantee values convergence is removed from the model. The relationship between independent variables and dependent variable groups is determined by Multivariate Regression Analysis. The value of the new variable in the research model is the average of the variables observing its component, the value of the components automatically calculated by SPSS software from the weighted average value of the observed variables were normalized. However, before conducting regression analysis, an important analysis should be performed first, a correlation analysis to test the linear correlation between variables in the model. Specifically, the study tested the correlation between the dependent variable and each independent variable and between the independent variables. Pearson correlation coefficients were used to quantify the degree of rigor of the linear relationship between two quantitative variables. The closer the absolute value of Pearson's coefficient is to 1 , the closer these two variables are linearly correlated (Chu Nguyen Mong Ngoc, 2008). In this study, expect a strong linear correlation between dependent variables and independent variables.

\section{Results}

\subsection{Situation of farmer contract between firms and farmers in Thai Binh province}

\subsubsection{Links between farmers and farmers}

According to Department of Agriculture and Rural Development of Thai Binh Province (2017), the whole province had 112 groups and affiliated groups in livestock production and aquaculture, 109 livestock groups/2,246 participating households, 3 aquaculture groups and 13 models of husbandry cooperation groups. The livestock groups are following the same VietGAP breeding process; Hold monthly meetings on disease prevention, input market problems and product consumption. The aquaculture group discussed looking for output, regulating harvesting time between households and time of product consumption for households. Collaborative groups have linked on breeds, feed, veterinary drugs, animal husbandry processes, lower production costs, improved product quality, and more concentrated product creation. Some cooperative groups and cooperatives have signed contracts with input suppliers and outlets. A number of large-scale self-invested farm owners are forming a chain of production with agreements to supply animal feed, veterinary drugs and consumption of livestock products.

Links between farmers and farmers in Thai Binh Province have been a horizontal linkages type. Farmers have joined together to create areas of specialized production of crop products with a larger scale and larger area. These links have helped them to sign contracts directly with the companies supplying raw materials in large quantities, the discount will be higher, and the quality of raw materials will be more guaranteed. Therefore, the product quality has been more uniform and input production cost has been more economical.

\subsubsection{Links between firms and farmers, between cooperatives and farmers}

Thai Binh province has 20 enterprises participating in linking with cooperatives and farmers; 4 livestock enterprises are linking with owners of livestock farms; 2 enterprises are linking with seafood production households. The form of these links are vertical linkages. There are many advantages to these links. First, it helps to effective cost management. Second, the quality of output products are more uniform. Third, it helps to keep price stability. Fourth, the supply and 
demand of the farming industry are more balanced, avoiding the situation of excess production, the price is squeezed, while the supply is scarce, the price is pushed up too high. Fifth, helping firms and farmers have the responsibility to come to the end of their products, from which information can be shared more easily, improving their competitiveness paintings of products.

Typical link models in Thai Binh province: (1) Farmer contract model of Japanese rice production and high quality rice. The area given for this farmer contract model accounted for $50.1 \%$ (4,892ha), being by far the largest one among farmer contract models. The main rice varieties include: ĐS1, Koshi, Bac Thom 7, BC15, T10, RVT, N97. (2) Farmer contract model of rice seed production. The area given for this farmer contract model comprised of $30.9 \%$ (3,015 ha). The main rice varieties include: BC15, TBR225, RVT, T10, Thien Uu 8, Nam Huong. (3) Farmer contract model of crop production. The area given for this farmer contract model accounted for $19.1 \%$ (1,859 ha). This model focuses mainly on areas with large areas of cash crops, riparian areas and areas dedicated to growing winter crops. The linked crops include: potatoes, sweet corn, squash, chili, baby cucumbers, and vegetables for export. (4) Farmer contract model with whiteleg shrimp farmers in Thai Thuy districts and Tien Hai districts. Every year, companies provide over 200 million of good quality shrimp seed to farmers. Besides, they also provide technical assistance and search for markets consuming over 200 tons of commercial shrimp.

\section{Table 2. Summary of data on production farmer contracts between companies and}

agricultural cooperatives in 2018

\begin{tabular}{|l|c|c|c|c|c|c|c|c|c|c|}
\hline Categories & Unit & $\begin{array}{c}\text { Thai } \\
\text { Binh } \\
\text { Seed } \\
\text { Company }\end{array}$ & $\begin{array}{c}\text { Hung } \\
\text { Cuc } \\
\text { Company } \\
\text { Limited }\end{array}$ & $\begin{array}{c}\text { Thai } \\
\text { Binh } \\
\text { Central } \\
\text { Seed } \\
\text { Company }\end{array}$ & $\begin{array}{c}\text { An Dinh } \\
\text { Investment } \\
\text { and } \\
\text { Development } \\
\text { Ltd. }\end{array}$ & $\begin{array}{c}\text { Lien } \\
\text { Hanh } \\
\text { Company } \\
\text { Limited }\end{array}$ & $\begin{array}{c}\text { Hai Duong } \\
\text { Agricultural } \\
\text { Import } \\
\text { Export } \\
\text { Company }\end{array}$ & $\begin{array}{c}\text { Other } \\
\text { companies }\end{array}$ & $\begin{array}{c}\text { Total } \\
\text { contracted } \\
\text { area (ha) }\end{array}$ & $\begin{array}{c}\text { Contracted } \\
\text { output } \\
\text { (tons) }\end{array}$ \\
\hline $\begin{array}{l}\text { Total linked } \\
\text { area }\end{array}$ & Ha & 2,666 & 1,600 & 295 & 900 & 385 & 1,298 & 2,622 & 9,766 & 7,907 \\
\hline Rice & Ha & 2,631 & 1,600 & 295 & 900 & 385 & 0 & 2,096 & 38,563 \\
\hline Vegetable & Ha & 35 & 0 & 0 & 0 & 0 & 1,298 & 526 & 1,859 & 32,947 \\
\hline $\begin{array}{l}\text { Number of } \\
\text { cooperatives }\end{array}$ & & 23 & 11 & 13 & 28 & 12 & 25 & 104 & 216 & \\
\hline
\end{tabular}

Source: Department of Agriculture and Rural Development of Thai Binh province (2019)

\subsubsection{Link between farmers and associations}

Currently in Thai Binh province, the way of link between farmers and associations are often through contracts. Accordingly, parties involved must comply with certain binding conditions that are specified in the contract, thus improving the responsibility of parties. In 2019, Thai Binh province had 80 communes in association with production with 20 companies and enterprises. Products contracted include: Rice seed, commercial rice, corn, millet, cucumber, squash, peanuts, spinach, potatoes...

Regarding the development of high-tech agriculture, there are now large corporations in renting land from farmers to develop clean agriculture, typically TH TRuemilk Group. TH TRuemilk invests in the production of clean and organic foods, in which rice, vegetables, tubers and fruits are the first product group implemented because it is an essential food for people. According to experts, the soil quality of Thai Binh is completely in line with TH TRuemilk's goals in investing in agriculture. According to the plan, TH TRuemilk Group will invest in developing hi-tech agriculture, developing tourism in association with planting medicinal herbs, 
models of clean vegetable cultivation, building agricultural processing plants and real oil plants material from rice bran in Thai Binh ... Project scales up to 3000ha of land with a total investment of 3,000 billion VND. Currently, TH TRuemilk Group has started to implement a project of 30ha planting clean vegetables on the land along Tra Ly River in Vu Thu District (Department of Agriculture and Rural Development of Thai Binh Province, 2019).

\subsection{Assess factors affecting the farmer contracts between firms and farmers}

\subsubsection{Cronbach's Alpha Analysis}

Cronbach's Alpha analysis results for the observed variables are described in the following table:

Table 3. Summary of scale test for independent and dependent variables

\begin{tabular}{|c|c|c|c|c|}
\hline No. & Code & Observed variables & Corrected & Cronbach's \\
Alpha if \\
Item-Total \\
Item \\
Deleted
\end{tabular}

Awareness of farmers about benefits of farmer contract with firms (NT), Cronbach's Alpha = 0.908

\begin{tabular}{|l|l|l|l|l|}
\hline 1 & NT01 & Output products are guaranteed to be consumed entirely by linked firms & .610 & .904 \\
\hline
\end{tabular}

\begin{tabular}{|l|l|l|l|l|}
\hline 2 & NT02 & The input services provided by linked firms with good quality & .812 & .887 \\
\hline
\end{tabular}

\begin{tabular}{|l|l|l|l|l|}
\hline 3 & NT03 & Product selling price can be guaranteed & .765 & .890 \\
\hline 4
\end{tabular}

\begin{tabular}{|l|l|l|l|l|}
\hline 4 & NT04 & Farmers inputs may be owed & .517 & .917 \\
\hline
\end{tabular}

\begin{tabular}{|l|l|l|l|l|}
\hline 5 & NT05 & Farmers have access to seedling services and plant protection services & .809 & .887
\end{tabular}

\begin{tabular}{|l|l|l|l|l|}
\hline 6 & NT06 & Farmers have access to crop technical services & .822 & .886 \\
\hline
\end{tabular}

\begin{tabular}{|l|l|l|l|l|l|}
\hline 7 & NT07 & Farmers can stabilize the price of their products by joining the link & .811 & .887 \\
\hline 8 & NT08 & Farmers can reduce product & 562 & 907 \\
\hline
\end{tabular}

\begin{tabular}{|l|l|l|l|}
\hline 8 & NT08 & Farmers can reduce product consumption costs by joining the link \\
\hline Commitments in the process of linking with firms $($ CK $)$, Cronbach's Alpha $=\mathbf{0 . 9 7 4}$
\end{tabular}

Commitments in the process of linking with firms (CK), Cronbach's Alpha $=\mathbf{0 . 9 7 4}$

\begin{tabular}{|l|l|l|l|l|}
\hline 9 & CK01 & Farmers are ready to sign cooperation documents with firms & .908 & 969
\end{tabular}

\begin{tabular}{|l|l|l|l|l}
\hline 10 & CK02 & $\begin{array}{l}\text { Farmers are willing to make commitments on linking with firms as well as } \\
\text { third parties (researchers) }\end{array}$ & .908 & .9690 \\
\hline
\end{tabular}

\begin{tabular}{|l|l|l}
11 & & Farmers are committed to following the production process according to the
\end{tabular}

11 CK03 instructions of the technical staff and recommendations of the agricultural $.948 \quad .965$

\begin{tabular}{|l|l|l|l|l|} 
& sector & & .948 & .965 \\
\hline 12 & CK04 & $\begin{array}{l}\text { Farmers are committed to providing firms with information on the production } \\
\text { process, use of varieties, medicines, harvesting time }\end{array}$ & .952 & .965 \\
\hline 13 & CK05 & $\begin{array}{l}\text { Farmers commit to sell products to enterprises according to specifications, } \\
\text { standards and quantity as the original commitment }\end{array}$ & .912 & .969 \\
\hline 14 & CK06 & Farmers are willing to follow legal constraints when linking with firms & .892 & .971
\end{tabular}

\begin{tabular}{|l|l|l|l|}
\hline 14 & CK06 & Farmers are willing to follow legal constraints when linking with firms & .892 \\
\hline \multicolumn{2}{|l}{ Sharing benefits and risks between farmers and linked firms (CS), Cronbach's Alpha $=\mathbf{0 . 8 9 8}$}
\end{tabular}

\begin{tabular}{|l|l|l|l|l|}
\hline 15 & CS01 & $\begin{array}{l}\text { Farmers are aware of the benefits brought about by linked with businesses } \\
\text { (guarantee of output consumption; access to seed and plant protection } \\
\text { services; stabilize the selling price of products; improve product quality..) }\end{array}$ & .717 & .889 \\
\hline 16 & CS02 & Farmers are willing to take risks when linking with firms & .810 & .855 \\
\hline 17 & CS03 & $\begin{array}{l}\text { Farmers are willing to share difficulties with firms when associating } \\
\text { (difficulties in production, consumption ...) }\end{array}$ & .822 & .856 \\
\hline 18 & CS04 & Farmers receive technical support, training, capital ... when linking with firms & .781 & .871 \\
\hline \multicolumn{7}{|l|}{ Management skills and business competence of linked firms (QL), Cronbach's Alpha = 0.850 } & .727 & .804 \\
\hline 19 & QL01 & Farmers are willing to link with firms with good management ability & .811 \\
\hline 20 & QL02 & Farmers are willing to link with firms with production and business capacity & .693 & .825 \\
\hline 21 & QL03 & Farmers are willing to link with firms with reputable firms in the locality & .638 & .712 \\
\hline 22 & QL04 & Farmers are willing to link with large-scale firms & .547 & .805 \\
\hline 23 & QL05 & Farmers are willing to link with firms with linked experiences & .850 \\
\hline
\end{tabular}

Policy environment - Institutions related to the farmer contract between firms and farmers (MT), Cronbach's Alpha $=\mathbf{0 . 8 1 0}$ 


\begin{tabular}{|c|c|c|c|c|}
\hline 24 & MT01 & $\begin{array}{l}\text { The State and local governments have good policies on linking production } \\
\text { and consumption in agricultural production }\end{array}$ & .659 & .755 \\
\hline 25 & MT02 & $\begin{array}{l}\text { Develop a strategy and plan for the production of agricultural products that is } \\
\text { suitable for linking }\end{array}$ & .653 & .756 \\
\hline 26 & MT03 & Local authorities select and implement appropriate farmer contracts & .593 & .775 \\
\hline 27 & MT04 & $\begin{array}{l}\text { The role of the state and local authorities in promoting the farmer contract } \\
\text { between farmers and firms (credit support, science and technology } \\
\text { support,...) }\end{array}$ & .645 & .759 \\
\hline 28 & MT05 & $\begin{array}{l}\text { The role of associations in promoting farmer contracts between farmers and } \\
\text { firms (Farmers' Union, Business Association,...) }\end{array}$ & .444 & .814 \\
\hline \multicolumn{5}{|c|}{$\begin{array}{l}\text { Price issues that farmers are interested in in the process of implementing farmer contracts with firms (GC), } \\
\text { Cronbach's Alpha }=0.747\end{array}$} \\
\hline 29 & GC01 & Farmers receive price support in case of crop failure or high price of inputs & .615 & .615 \\
\hline 30 & GC02 & Linked firms offer reasonable buying prices to farmers & .590 & .590 \\
\hline 31 & $G C 03$ & $\begin{array}{l}\text { The company guarantees to make the purchase price as committed and not } \\
\text { reduce the purchase price in case of crop success }\end{array}$ & .769 & .769 \\
\hline \multicolumn{5}{|c|}{ The level of participation of farmers in the linking process (TG), Cronbach's Alpha $=0.925$} \\
\hline 32 & TG01 & $\begin{array}{l}\text { Farmers are interested in associating with firms in production and } \\
\text { consumption of products }\end{array}$ & .872 & \\
\hline 33 & TG02 & Farmers are willing to link with firms & .872 & \\
\hline
\end{tabular}

Source: Summary of the author (2019)

The summary results in Table 4 show that most of the scales had Cronbach Alpha coefficient in the range of 0.7-0.8 so the scales in this study were highly reliable. The results shown in Table 4 indicate that there were 3 observed variables excluded due to the failure of Cronbach Alpha coefficients and the total correlation (NT04, MT05, GC03).

\subsubsection{Exploratory Factor Analysis (EFA)}

After assessing the reliability of the scales, the author conducted an exploratory factor analysis to evaluate the convergence value and discriminant value of the independent and dependent variable scales.

Table 4. Exploratory factor analysis results for the independent variables

\begin{tabular}{|c|c|c|c|c|c|}
\hline & \multicolumn{5}{|c|}{ Factor } \\
\hline & 1 & 2 & 3 & 4 & 5 \\
\hline CK04 & .973 & & & & \\
\hline CK03 & .970 & & & & \\
\hline CK05 & .931 & & & & \\
\hline $\mathrm{CS} 02$ & .883 & & & & \\
\hline CK01 & .882 & & & & \\
\hline CK06 & .880 & & & & \\
\hline CK02 & .844 & & & & \\
\hline $\mathrm{CS} 03$ & .801 & & & & \\
\hline CS04 & .770 & & & & \\
\hline CS01 & .721 & & & & \\
\hline NT07 & & .914 & & & \\
\hline NT05 & & .892 & & & \\
\hline NT06 & & .858 & & & \\
\hline NT03 & & .839 & & & \\
\hline NT02 & & .820 & & & \\
\hline MT03 & & & .848 & & \\
\hline MT01 & & & .799 & & \\
\hline MT04 & & & .792 & & \\
\hline MT02 & & & .760 & & \\
\hline
\end{tabular}




\begin{tabular}{|c|c|c|c|c|c|}
\hline \multicolumn{4}{|l|}{ QL02 } & \multicolumn{2}{|l|}{.972} \\
\hline QL01 & & & & .946 & \\
\hline GC01 & & & & & .908 \\
\hline GC02 & & & & & .852 \\
\hline Eigenvalues & 10.668 & 2.442 & 2.156 & 1.492 & 1.081 \\
\hline $\begin{array}{l}\text { Average variance extracted } \\
\mathrm{KMO}=0.909\end{array}$ & 46.384 & 57.004 & 66.380 & 72.865 & $\begin{array}{l}77.563 \\
\text { Sig }=0.000\end{array}$ \\
\hline
\end{tabular}

Source: Summary of the author (2019)

In this study, the KMO value was 0.909 (KMO > 0.7) and Bartlett's test of sphericity had a significant value $=.000$ (less than .05 ). These results suggest that factor analysis was suitable for these statements. In the extraction of the EFA, based on the initial eigenvalues greater than 1, the analysis output showed five components were the factors in this EFA. The percentage of explained variance was $77.563 \%$. In all statements, the factor larger than 0.5 suggests that the statements can optimally explain variances of their related factors, and thus the questions are significant.

Thus, the factors after implementing EFA discovery factor ensure the ability to represent the original survey data and be eligible to perform multivariate regression analysis. Five factors were drawn from the implementation of the EFA analysis, including: (1) Commitment and sharing of benefits and risks between farmers and firms in the linking process, (2) Household awareness about the benefits brought about by farmer contracts with firms, (3) Policy environment Institutions related to farmer contracts between firms and farmers, (4) Issues related to management skills and enterprises capacity of link firms, (5) Price issues that farmers are interested in in the process of implementing links with firms. Thus, the EFA factor analysis results have changed the group of variables compared to the original theoretical model.

\subsubsection{Exploratory Factor Analysis for dependent variables}

Result of the Kaiser Meyer Olkin value was .905 (KMO > 0.7) and Bartlett's test of sphericity had a significant value $=.000$ (less than .05 ). These results suggest that factor analysis was suitable for these statements. There are one dimension or component emerged from the EFA procedure based on the computed Eigenvalue $>1.0$. The extracted variance reached $93,617 \%$. This has confirmed the ability to converge and perform well of the observed observation variables.

\subsubsection{Testing model and hypotheses}

\subsubsection{Correlation analysis}

The results of correlation analysis showed that all independent variables were correlated with dependent variables. Dependent variable - The level of participation of farmers in the process of linking with firms the level of participation of farmers in the process of linking with firms (Y) had the strongest correlation with the independent variable - Commitment and sharing of benefits and risks between farmers and firms in the linking process (X1), with a Pearson correlation coefficient of 0.734 . In contrast, the dependent variable $Y$ had the weakest correlation with the independent variable - Policy environment - Institutions related to farmer contracts between firms and farmers, with the Pearson correlation coefficient of 0.422 . This strong correlation was expected because it was the linear tight relationships between the variables that explain the effect on the model results. Therefore, these independent variables can be included in the regression analysis to explain the influence of the results of the research model.

\subsubsection{Multivariate regression analysis}


Multivariate regression analysis was performed with 5 independent variables and the selection method was Enter. The results of multivariate regression analysis were as follows:

Table 5. Summary of regression model

\begin{tabular}{|c|c|c|c|c|c|c|c|c|}
\hline \multirow{2}{*}{\multicolumn{2}{|c|}{ Model }} & \multicolumn{2}{|c|}{$\begin{array}{l}\text { Unstandardized } \\
\text { Coefficients }\end{array}$} & \multirow{2}{*}{$\begin{array}{l}\text { Standardized } \\
\text { Coefficients } \\
\text { B }\end{array}$} & \multirow[t]{2}{*}{$\mathrm{T}$} & \multirow[t]{2}{*}{ Sig. } & \multicolumn{2}{|c|}{ Multicollinearity } \\
\hline & & B & $\begin{array}{l}\text { Std. } \\
\text { Error }\end{array}$ & & & & Tolerance & $\begin{array}{l}\text { Variance inflation } \\
\text { factor (VIF) }\end{array}$ \\
\hline \multirow[t]{6}{*}{1} & (Constant) & 2.102 & .353 & & 5.950 & .000 & & \\
\hline & $\mathrm{X} 1$ & .732 & .066 & .523 & 11.010 & .000 & .553 & 1.807 \\
\hline & $\mathrm{X} 2$ & .091 & .072 & .057 & 1.269 & .000 & .618 & 1.619 \\
\hline & $\mathrm{X} 3$ & .231 & .089 & .105 & 2.598 & .010 & .768 & 1.302 \\
\hline & $\mathrm{X} 4$ & .222 & .047 & .186 & 4.687 & .000 & .791 & 1.263 \\
\hline & $\mathrm{X} 5$ & .281 & .062 & .184 & 4.518 & .000 & .757 & 1.321 \\
\hline & $=0.634$ & \multicolumn{3}{|c|}{ Adjusted R-squared $=0.628$} & 3) $=10$ & & \multicolumn{2}{|l|}{$\mathrm{p}=0.00$} \\
\hline
\end{tabular}

An examination of Table 5 makes it clear that the five independent variables in the standard model are significantly predictive of the dependent variable $\mathrm{Y}$ according to the ANOVA statistics $[\mathrm{F}(5,293)=101.452, \mathrm{p}<.05]$. Analysis of variance $($ ANOVA), the model has Sig. $=$ $0,000(<0.05)$ so the independent variables are linearly correlated with the dependent variables. On the other hand, the model had no multicollinearity due to Variance Inflation Factors (VIF) < 2 (Moderately correlated).

The $\mathrm{R}^{2}$ value was 0.628 , it means that $62.8 \%$ of the variation in the dependent variable $\mathrm{Y}$ is explained by the independent variable in the regression model, the remaining $37.2 \%$ was due to non-model variables and random errors. Looking at these coefficients, it may be said that the model predicts the dependent variable good.

Based on the regression analysis results, the regression equation was obtained as it is shown below:

$$
\mathrm{Y}=2.102+0.732 \mathrm{X} 1+0.091 \mathrm{X} 2+0.231 \mathrm{X} 3+0.222 \mathrm{X} 4+0.281 \mathrm{X} 5
$$

\section{Discussion}

As described above, the degree of farmers participation in the link was classified according to five factors: Commitment and sharing of benefits and risks, household awareness about the benefits of contracts, policy environment, management skills and enterprises capacity of link firms and price issues. Regarding the factor of commitment and sharing of benefits and risks, all 10 variables had factor loading scores between .721 and .973, and the top-3 factor loading scores were the farmers are committed to providing information for firms (CK04; .973), following the production process $(\mathrm{CK} 03 ; .970)$, selling products to enterprises as the original commitment (CK05; .931). For the factor of household awareness about the benefits of contracts, there were 5 variables which had factor loading scores between .820 and .914 , and the highest factor loading score was the farmers can stabilize the price of their products by joining the link (NT07; .914). For the factor of policy environment, there were 4 variables which had factor loading scores between .760 and .848 . For the factor of management skills and enterprises capacity of link firms, there were 2 variables which had factor loading scores between .946 and .972 . For the factor of price issues, there were 2 variables which had factor loading scores between .908 and .852 .

The absolute value of $\beta$ (Beta) in Table 5 indicates the order of importance of the independent variables. The variable with the highest $\beta$ value is the relatively most important independent variable. On examining the contributions made by the independent variables in the model to the model, it was found that the Commitment and sharing of benefits and risks between farmers and 
firms in the linking process made the biggest contribution with the value of $(\beta=0.732)$. It was followed by the Price issues that farmers are interested in in the process of implementing links with firms, Policy environment - Institutions related to farmer contracts between firms and farmers, Issues related to management skills and firms capacity of link firms, Household awareness about the benefits brought about by farmer contracts with firms. In fact, these figures were $0.281,0.231$, $0.222,0.091$, respectively. All the factors in the regression model had a positive effect on participation of farmers (coefficient a_i $>0$ ).

\section{Conclusions and Implications}

Based on secondary data and primary data from the 300 farmers survey of Thai Binh province, using the method of economic statistical analysis, comparative method, exploratory factor analysis method. The study has assessed and analyzed the status of farmer contracts through basic links: First, the link between farmers and farmers in Thai Binh was vertical linkages. Farmers join together to create areas of specialized production of crop products with a larger scale and larger area. Second, farmer contracts between farmers and firms, between farmers and cooperatives have been vertical links. This form helps linked firms and farmers in Thai Binh province have the responsibility to come to the end of their products, from which information can be shared more easily and improve competitiveness of the product. Third, the research analyzed the farmer contracts between farmers and firms. This form of farmer contracts between farmers and firms will help develop the crop sector in the province to achieve higher economic efficiency. Contracting parties must have certain binding conditions stipulated in the contract of agreement, thereby improving the responsibility among the participating parties.

The research has analyzed the basic factors affecting the level of participation of farmers in the process of linking with firms, thereby proposing the main solutions to strengthen farmer contracts between firms and farmers in crop production

First, completing the system and policy environment, especially the process of agricultural land accumulation.

Second, strengthen the management capacity and business capacity of linked firms. It is necessary to have solutions to improve the management skills and business capacity of linked firms in Thai Binh province. When signing contracts with farmers, firms need to have clear constraints and strong enough sanctions.

Third, promoting the development of a value-added chain model, this is considered as an important solution to accelerate the farmer contract process between farmers and firms. In particular, firms play an important role in implementing links. For example, reaching new markets, finding outlets for product consumption, bridging helps farmers reorganize the production of agricultural goods in accordance with the process, standards, and requirements for the quality of agricultural products that the market needs. As a result, it helps to expand production scale through land accumulation, development of large sample fields, and construction of value chains in agricultural commodity production.

Fourth, developing production links, concentrating agricultural land, applying science and technology into production, establishing production farmer contract chain of crop production. At the same time, the local government should continue to assess the examples of high-efficiency, chain-based production farmer contracts that serve as a basis for future replication.

Fifth, in order for the process of farmer contracts between firms and farmers households to be developed stably and sustainably, it is necessary to promote solutions on developing commodity markets for agricultural products. In addition, Thai Binh province needs to have policies to 
promote the image of agricultural products of the province in a broad manner in depth, expanding domestic and international consumer markets with key agricultural products of the province such as rice, melon, sugar beets.

\section{References}

Bao Loan \& Duong Thanh (2019). Link between Firms and Farmers: Motivation to develop commodity production. Newspaper business forum. https://enternews.vn/rao-can-thuong-maingay-cang-phuc-tap-trong-xuat-khau-nong-san-159374.html

Boehlje, M. (2000). Critical dimensions of structural change. Unpublished document, Department of Agricultural Economics. West Layafette: Purdue University.

Carney, J. A. (1988). Struggles over crop rights and labour within contract farming households in a Gambian irrigated rice project. The Journal of Peasant Studies, 15(3), 334-349.

Center for Flowers, Ornamentals Research and Development (2020). Linkages farmers and firms. http://ceford.vn/tin-tuc/tang-cuong-lien-ket-giua-nong-dan-voi-doanh-nghiep

Cerny, B. A., \& Kaiser, H. F. (1977). A study of a measure of sampling adequacy for factoranalytic correlation matrices. Multivariate behavioral research, 12(1), 43-47.

Chu Nguyen Mong Ngoc (2008), Analyze data research with SPSS. Hong Duc Publishing House. 38-41.

Clapp, J. (1994). The toxic waste trade with less-industrialised countries: Economic linkages and political alliances. Third World Quarterly, 15(3), 505-518.

Coe, D. T., \& Helpman, E. (1995). International r\&d spillovers. European economic review, 39(5), 859-887.

Coe, D. T., Helpman, E., \& Hoffmaister, A. W. (1997). North-south R \& D spillovers. The Economic Journal, 107(440), 134-149.

Cristobal, E., Flavian, C., \& Guinaliu, M. (2007). Perceived e-service quality (PeSQ). Managing service quality: An international journal.

Cronbach, L. J. (1951). Coefficient alpha and the internal structure of tests. psychometrika, 16(3), 297-334.

Delgado, C. (1999). Sources of growth in smallholder agriculture in sub-Saharan Africa: The role of vertical integration of smallholders with processors and marketers of high value-added items. Agrekon, 38, 165-189.

Department of Agriculture and Rural Development of Thai Binh Province (2019). Summary of agriculture sector

Dieppe, A., \& Mutl, J. (2012). International R\&D spillovers: technology transfer vs. R\&D synergies. European Central Bank, Working Papers Serries, No.1504.

Fujita, M., \& Mori, T. (2005). Transport development and the evolution of economic geography. Portuguese Economic Journal, 4(2), 129-156.

General Statistics Office (2017). Results of the Rural, Agriculture and Fishery Census.

Giroud, A., \& Scott-Kennel, J. (2006). Foreign-local linkages in international business: A review and extension of the literature. Bradford University, School of Management.

Habidin, N. F. (2013). Critical success factors of Lean Six Sigma for the Malaysian automotive industry. International Journal of Lean Six Sigma. 60-82. 
Hatcher, L. (1994). A step-by-step approach to using the SAS system for factor analysis and structural equation modeling. Cary, North Carolina: SAS Institute.

Hélène A. Ba , Yann de Mey, Sylvie Thoron, Matty Demont (2019). Inclusiveness of contract farming along the vertical coordination continuum: Evidence from the Vietnamese rice sector. Land Use Policy, 87, 104050. https://doi.org/10.1016/j.landusepol.2019.104050.

Hirschman, A. O. (1958). The strategy of economic development (No. 04; HD82, H5.).

Hudson, D. (2000). Contracting in Agriculture: A Primer for Leaders Research report 20002007. Department of Agricultural Economics, Mississippi State University. Industry, Wageningen Agricultural University, The Netherlands, 393-403.

Hung Anh, N., \& Bokelmann, W. (2019). Determinants of smallholders' market preferences: The case of sustainable certified coffee farmers in Vietnam. Sustainability, 11(10), 2897.

Hussain, M. N., \& Planning, S. (2000). Linkages between SMEs and large industries for increased markets and trade: an African perspective.

Jackson. Jc \& Cheacher. Ap. (1994). Contract farming in Zimbabwe: case studies of sugar, tea and cotton. In Little, PD \& Watts, MJ (Eds), Living under contract. Madison, WI: University of Wisconsin Press.

Kaiser, H. F. (1974). An index of factorial simplicity. Psychometrika, 39(1), 31-36.

Kilmer, R. L. (1986). Vertical integration in agricultural and food marketing. American Journal of Agricultural Economics, 68(5), 1155-1160.

Latif, S. A., Omar, M. S., Bidin, Y. H., \& Awang, Z. (2012). Environmental problems and quality of life: situational factor as a predictor of recycling behaviour. Procedia-Social and Behavioral Sciences, 35, 682-688.

Latif, S. A., Omar, M. S., Bidin, Y. H., \& Awang, Z. (2018). Analyzing the effect of situational factor on recycling behaviour in determining the quality of life. Journal of Asian Behavioural Studies, 3(6), 11-17.

Le Thi Kim Oanh, Vu Dinh Ton, Tran Huu Cuong, Philippe Lebailly (2016). Contract Farming as a Determinant of Promoting Tea Marketing Channels for Small Producers in Phu Tho Province. International Review of Research in Emerging Markets and the Global Economy, 2(4), 955-972.

Levin, R. (1988). Contract farming in Swaziland: Peasant differentiation and the constraints of land tenure. African Studies, 47(2), 101-120.

Little, P. D., \& Watts, M. (Eds.). (1994). Living under contract: contract farming and agrarian transformation in sub-Saharan Africa. Univ of Wisconsin Press.

Mesquita, L. F., \& Lazzarini, S. G. (2009). Horizontal and vertical relationships in developing economies: Implications for SMEs' access to global markets. In New Frontiers in Entrepreneurship (pp. 31-66). Springer, New York, NY.

Nguyen Dinh Phuc, Phan Thi Diem, Giap Thi Thuy Dung \& Ngo Thi Le Thuy (2017). Factors affecting the ability to join sugarcane production and consumption models of sugarcane growers with Gia Lai sugarcane thermal power company. Journal of Science - Hue University. 126 (5A). 43-61.

Nguyen Tat Thang (2014), Research solutions to strengthen linkages between farmers, scientists and enterprises in agricultural production and business in the Red River Delta. Hanoi University of Agriculture. National political publishing house. 
Nguyen Van Chi (2020), Linking from production to consumption of agricultural products in Hanoi: reality and problems to be solved. Vietnam Gardening Association. http://www.vacvina.org.vn/xem-tin-tuc/lien-ket-tu-san-xuat-den-tieu-thu-san-pham-trongnong-nghiep-ha-noi-thuc-tai-va-nhung-van-de-can-giai-quyet.html.

Norris, M., \& Lecavalier, L. (2010). Evaluating the use of exploratory factor analysis in developmental disability psychological research. Journal of autism and developmental disorders, 40(1), 8-20.

Nunnally, J. C. (1978), Psychometric theory. McGraw-Hill.

Olounlade, O. A., Li, G. C., Kokoye, S. E. H., Dossouhoui, F. V., Akpa, K. A. A., Anshiso, D., \& Biaou, G. (2020). Impact of Participation in Contract Farming on Smallholder Farmers' Income and Food Security in Rural Benin: PSM and LATE Parameter Combined. Sustainability, 12(3), 901.

Pasour, E. C. (1998). The potential impact of increased vertical integration on North Carolina grain farmers. North Carolina State University, Raleigh.

Quang Sang (2019). Farmers and firms still find it hard to find common ground. The voice of Vietnam online. https://vov.vn/kinh-te/nong-dan-va-doanh-nghiep-van-kho-tim-tieng-noichung-896777.vov.

Quynh Anh (2020). Enhancing the value chain linkage between cooperatives and agricultural product processing firms. http://baokiemtoannhanuoc.vn/goc-nhin-chuyen-gia/tang-cuonglien-ket-chuoi-gia-tri-giua-hop-tac-xa-va-doanh-nghiep-che-bien-nong-san-142407.

Reardon, T., \& Barrett, C. B. (2000). Agroindustrialization, globalization, and international development: an overview of issues, patterns, and determinants. Agricultural economics, 23(3), 195-205.

Royer, J. S. (1995). Potential for cooperative involvement in vertical coordination and valueadded activities. Agribusiness, 11(5), 473-481.

Runsten, D., \& Key, N. (1996). Contract farming in developing countries: Theoretical aspects and analysis of some Mexican cases. Report prepared for the United Nations Economic Commission for Latin America and the Caribbean, Santiago, Chile.

Saggi, K. (2002). Trade, foreign direct investment, and international technology transfer: A survey. The World Bank Research Observer, 17(2), 191-235.

Sporleder, T. L. (1992). Managerial economics of vertically coordinated agricultural firms. American Journal of Agricultural Economics, 74(5), 1226-1231.

Staatz, J. M., \& Eicher, C. K. (1998). Agricultural development ideas in historical perspective. International agricultural development, 3.

Thai Binh Statistical Office (2017). Social and economic situation in 2017.

Tran Quoc Nhan (2012). Analyzing the causes leading to the weak implementation of contracts on the consumption of agricultural products between farmers and enterprises in Vietnam. Journal of science and development Viet Nam. 10 (7). 1069-1077.

Unctad (2001). World investment report: Promoting farm contracts.

Vellema, S. (2000). Technology and control in Philippine contract farming: the cases of asparagus production and maize seed production. International Journal of the Sociology of Agriculture and Food, 8(1), 25-34.

Vo Huu Phuoc (2014), Researching and applying the model of linking 4 houses to rural agricultural production practices in Tra Vinh province. Academy of Social Sciences. 
Watts, M. J. (1994). Life under contract: contract farming, agrarian restructuring, and flexible accumulation. Living under contract: contract farming and agrarian transformation in subSaharan Africa, 21-77.

Williams. S, (1985) The Mumias Sugar Company: a nucleus estate in Kenya. In Williams, S (Ed.), Agribusiness and the small-scale farmer. Boulder, CO: Westview. 